\title{
Radial distribution of non-structural carbohydrates in Malaysian teak
}

\author{
F. Bobelé NIAMKE ${ }^{1,5,6,7 *}$, N. AMUSANT ${ }^{1}$, A. D. KOKUTSE ${ }^{2}$, G. CHAIX ${ }^{3}$, J. P. \\ CHARPENTIER $^{4}$, A. A. ADIMA ${ }^{5}$, S. KATI-KOULIBALY ${ }^{6}$, C. JAY-ALLEMAND ${ }^{7}$ \\ ${ }^{1}$ Unité de Recherche Préservation des Bois Tropicaux, CIRAD/FORET 73, rue Jean-François Breton TA 10/16 \\ 34398 Montpellier Cedex 5, France. \\ ${ }^{2}$ Laboratoire de Botanique et Ecologie Végétale, Faculté des Sciences, Université de Lomé, \\ BP: 1515, Lomé, Togo, Tel: (+228) 225-50-94, Fax: (+228) 221-85-95. \\ ${ }^{3}$ Unité de recherche Diversité Génétique et Amélioration des Espèces Forestières, CIRAD/FORET 73, rue \\ Jean-François Breton TA 10/16 34398 Montpellier Cedex 5, France. \\ ${ }^{4}$ INRA Orléans, Unité de Recherche Amélioration, Génétique et Physiologie Forestières (AGPF), GENOBOIS, \\ 2163 avenue de la Pomme de Pin CS 40001 Ardon 45075 Orléans Cedex 2, France. \\ ${ }^{5}$ Laboratoire de Procédés Industriels de Synthèse de l'Environnement et de l'Energie Nouvelle (LAPISEN), \\ unité Chimie des Eaux et des Substances Naturelles, Institut National Polytechnique Houphouët Boigny, B.P. \\ 1313 Yamoussoukro, Côte d'Ivoire. \\ ${ }^{6}$ Laboratoire de Nutrition et Pharmacologie de l'UFR Biosciences 22 BP 582 Abidjan 22 Côte d'Ivoire. \\ ${ }^{7}$ Laboratoire de Biochimie et de Physiologie Végétales, UMR 188 (DIAPC), Equipe Rhizogenèse, Université \\ Montpellier II, Place Eugène Bataillon, 34095 Montpellier Cedex 05 France. \\ ${ }^{*}$ Corresponding author, E-mail: bobeleflo@yahoo.fr, Fax: 0033 (0) 467616560 / 0033 (0) 467615725
}

\section{ABSTRACT}

Non-structural carbohydrates are primary compounds whose distribution in the wood affects its properties. During the two last decades, a high variability of natural durability of plantation teak wood properties has been found with consequences for industry and consumers. In order to further investigate chemical traits for natural durability in Malaysian teak, we studied the radial distribution of main non-structural carbohydrates (NSC) from the sapwood to the inner heartwood. NSC were analysed by thin layer chromatography coupled to an enzymatic method. The main NSC were starch, glucose, fructose and sucrose. Stachyose and raffinose were also detected. Starch was the major NSC while sucrose was the less abundant. NSC were highly accumulated in sapwood and decreased drastically in heartwood. In our sampling, NSC distribution patterns were the same between trees but were different on a quantitative point of view. Our results suggested that NSC were stored as reserve materials in the sapwood and then were used in the sapwoodheartwood boundary for metabolic activities during heartwood formation process. Their involvement in heartwood formation was discussed.

() 2010 International Formulae Group. All rights reserved.

Keywords: Tectona grandis, sapwood, heartwood, non-structural carbohydrates, starch.

\section{INTRODUCTION}

Teak, Tectona grandis L. f. (Verbenaceae) is native of south-eastern Asia (Behaghel, 1999) and is one of the most valuable tropical hardwood species on the international market (Pandey and Brown, 2000). Due to its natural durability, aesthetic and technological properties (Thulasidas et al., 
2006; Bhat et al., 2005), teak is often used for outdoor purposes, e.g. boat decks, bridge building, and garden furniture, as well as traditional indoor uses, e.g. flooring and furnishings. Teak has a long history as plantation species due to its valuable timber, and has been introduced successfully as an exotic species in tropical zone (Kaosa-ard, 1999). Today it is considered as one of the most promising out crossing plantation species in the tropics (Goh and Monteuuis, 2009). But, the use of shortened rotation time for plantation management has induced a high variability in teak wood properties such as natural durability particularly, decay resistance, strength, etc. (Bhat and Florence, 2003; Bhat et al., 2005).

It has been shown that natural durability in teak from Costa Rica is not related to the wood physical properties such as the wood density or the wood fibre characteristics (Moya et al., 2009). But, it is related to the accumulation of toxic heartwood extractives which occurred during heartwood formation process (Thulasidas and Bhat, 2007; Datta and Kumar, 1987). Heartwood formation starts when trees are 6 to 8 years old (Kokutse et al., 2004). At this age, it can develop up to 30-35 years and then slows down (Kokutse et al., 2004). Many factors can affect heartwood formation in rapid plantation-grown teak but the most important is the radial growth which depends on environmental conditions (the annual precipitation, temperature and the stand) (Kokutse et al., 2010). On a biochemical level, it was observed that metabolic activities throughout the sapwood and within the transition zone which is the intermediate zone between the sapwood and the heartwood, lead to the biosynthesis of heartwood extractives. Based on histochemical methods, it has been shown that non-structural carbohydrates (NSC; mainly starch) and lipids were used for metabolic activities and also for heartwood extractive synthesis (Datta and Kumar, 1987; Nobuchi et al., 1996; Nobuchi et al., 2005). Therefore, the chemical characterisation of the wood on the radial profile could be a means to better understand heartwood formation which has a large impact on wood quality.

In temperate trees, heartwood formation process is well documented and several patterns of non-structural carbohydrates were described (Magel et al., 1997; Magel and Höll, 1993). For example, in Robinia (Robinia pseudoacacia) or beech (Fagus species), NSC, mainly starch and sucrose, accumulate in young living cells of the wood and deplete abruptly in the oldest ones (Magel et al., 1997). While in Juglans species, storage NSC depletes dramatically from the sapwood to the heartwood, but a high accumulation of glucose released from phenol glucoside hydrolysis occurred in the heartwood (Magel et al., 2001; Duroux et al., 1998).

In tropical species, the involvement of non-structural carbohydrates in heartwood formation has been described (Nobuchi et al., 2005). However, quantitative information about their role in heartwood formation and its relationship to decay resistance is still lacking. Because of the high variability of teak wood natural durability, identifying some chemical traits for this property with reference to heartwood formation process will provide useful information for wood professionals and consumers. The first step is to characterise the main chemical compounds.

Therefore, the present paper focused on the radial distribution of major non-structural carbohydrates (NSC) in the stem of Malaysian plantation teak. The main NSC were characterised by thin layer chromatography and their contents were analysed using spectroscopic methods after enzymatic assays. The deep difference in the content of non- 
structural carbohydrates between the sapwood and the heartwood allows discussing about heartwood formation process.

\section{MATERIALS AND METHODS}

Seven trees of teak ranging in age from 5.5 to 10 years (Table 1) were felled in May 2004 from Luasong and Taliwas, Sabah in the east of Malaysia. The climate in those areas is similar for the two sites and is characterized by annual South-West (April to October) and North-East (October to February) monsoons. Average annual rainfall is more than $2500 \mathrm{~mm}$ (Goh and Monteuis, 2009). Two seasons are distinguished: the rainy / wet season and the dry season. The wet season starts in November and ends towards April (www.sabah.com.my).

One log was cut at breath height for each tree from which a transversal wood slice was removed. The transversal wood slice was air dried and conditioned in a climatic room (Humidity: $65 \% \pm 5$, temperature: $20{ }^{\circ} \mathrm{C} \pm 1$ ${ }^{\circ} \mathrm{C}$ ) until their usage, leading to $12 \%$ of the wood moisture content. From well-identified tree slices, four wood blocks $(25 \times 25 \times 10$ $\mathrm{mm}$ in the radial, the tangential and the longitudinal directions respectively) were taken successively from the sapwood to the pith: sapwood (SW), outer heartwood (OHW), middle heartwood (MHW), inner heartwood (IHW; Fig. 1) at a relative distance of 0.9, 0.6, 0.4 and 0.15 respectively to the total length of the radius. From the tree 5 which had more sapwood, five wood samples were taken successively from the sapwood to the pith in the outer sapwood (OSW), inner sapwood (ISW), outer heartwood (OHW), middle heartwood (MHW), inner heartwood (IHW). OSW and ISW results were mixed for calculations. From tree 7, which presented eccentric heartwood, three samples were taken in the SW, OHW and IHW only. All samples were ground into a fine powder using a grinder (Reisch ZM 200).

\section{Chemical analyses}

All the solvents (acetone, acetonitrile, ethanol and methanol) used in this study were HPLC grade.

\section{Extraction of non-structural carbohydrates (NSC)}

Extraction was performed as described by Silpi et al. (2007) with a few modifications. Wood powder $(50 \mathrm{mg})$ was extracted three times with $1 \mathrm{~mL}$ of ethanol/water $(80: 20, \mathrm{v} / \mathrm{v})$ for $30 \mathrm{~min}$ at $90^{\circ} \mathrm{C}$ and then centrifuged $(13,400 \mathrm{rpm})$. The supernatants were treated with polyvinylpolypyrrolidone (PVPP; Fluka, Switzerland) and active charcoal (Aldrich, Steinheim Germany) to remove polyphenols and pigments. The filtrates were dried under nitrogen flow overnight. The dry extract was dissolved in pure water and used for the measurements. The remaining residue was used for the extraction and the analysis of starch. Starch was hydrolyzed from the remaining residue with $1 \mathrm{~mL}$ of sodium hydroxide for one hour at $90{ }^{\circ} \mathrm{C}$. After incubation $\left(50 \quad{ }^{\circ} \mathrm{C}, \quad 1\right.$ hour $)$ with amyloglucosidase (E.C. 3.2.1.3; 7U; Fluka, Switzerland) activated in a citrate buffer, aliquots of $50 \mu \mathrm{L}$ were essayed for glucose as described by Magel and Höll (1993). All experiments were performed in triplicate.

\section{Thin layer chromatography of soluble non- structural carbohydrates (NSC)}

NSC were analysed by a method as described by Magel and Höll, (1993). 20 mg of wood powder was extracted as describe above. Dried extracts were dissolved in $20 \mu \mathrm{L}$ of a solution of methanol / water $(75: 25 ; \mathrm{v} / \mathrm{v})$. $10 \mu 1$ were spotted on a TLC plate (silica gel 60, Merck Darmstadt, Germany). The plate was developed three times in chloroform / 
acetic acid / water (6/7/1, v/v/v). Spots were visualized by spraying with diphenylamine / aniline / acetone / orthophos-phoric acid $(1 / 1 / 100 / 10, \mathrm{w} / \mathrm{v} / \mathrm{v} / \mathrm{v})$ and heated to $130^{\circ} \mathrm{C}$ for 3 min. Spots were identified by cochromatography of authentic NSC obtained from Aldrich (Steinheim, Germany). The study was carried out with tree-5 having larger sapwood, in the outer sapwood (OSW), inner sapwood (ISW) and the outer heartwood (OHW).

\section{Quantification of non-structural carbohydrates (NSC) \\ Main NSC (starch, glucose, fructose} and sucrose) were measured enzymatically by UV methods as described by Silpi et al. (2007) with a spectrophotometer (Bio-Tek Instruments). Glucose and fructose were determined directly, sucrose and starch were determined after enzymatic hydrolysis. The content of soluble NSC is expressed as $\mu$ moles per gram (g) dry weight (dw) and the content of starch is expressed as $\mu$ moles bond glucose per gram (g) dry weight.

\section{Statistical analysis}

Differences in non-structural carbohydrates content at inter-tree level and between radial positions were carried out using the non-parametric Mann-Whitney test. The effect of tree on the content of nonstructural carbohydrates was studied using the non-parametric Krulkarl Wallis test because the data did not fulfil the criteria for a parametric test. Values were considered to be statistically significant at $\mathrm{p} \leq 0.05$. The XLSTAT software package was used for the statistical analysis.

\section{RESULTS \\ Identification of non-structural carbohydrates (NSC) by thin layer chromatography \\ Figure 2 shows thin layer chromatography results in outer, inner}

sapwood and outer heartwood in comparison to authentic NSC (glucose, fructose, sucrose, stachyose and raffinose). Glucose $(\mathrm{Rf}=0.60)$, fructose $(\mathrm{Rf}=0.65)$, sucrose $(\mathrm{Rf}=0.42)$, stachyose $(\mathrm{Rf}=0.08)$, raffinose $(\mathrm{Rf}=0.20)$ and two unknown NSC ( Rfs $=0.02$ and 0.28 respectively) were identified in the outer sapwood of teak. With the importance of revealed spots, the major fractions were fructose, sucrose and glucose. On the radial direction, NSC accumulated in the outer sapwood and decreased from the outer sapwood to the outer heartwood.

\section{Quantitative variations of non-structural carbohydrates (NSC) through the stem}

Soluble NSC: glucose, fructose and sucrose as shown by thin layer chromatography together with starch constituted the dominant fraction of sapwood. Quantitative results are depicted in Figure 3. Starch content is six-fold higher than glucose and fructose, and 15-fold higher than that of sucrose. Therefore, starch was the major NSC found in teak. It represented $72 \%$ of total NSC (Table 1). In the sapwood, starch content was high (70 $\mu \mathrm{mol} . \mathrm{g}^{-1} \mathrm{dw}$; Figure 3A) and decreased drastically to the outer heartwood. In heartwood, the amounts of starch were low (0.2 $\mu$ moles. $\left.\mathrm{g}^{-1} \mathrm{dw}\right)$. The concentration of starch decreased with the distance to the pith.

Preponderant soluble NSC in teak wood were glucose, fructose, and sucrose. Soluble NSC contents were higher in sapwood than heartwood (Figure 3B). This observation was in good accordance with thin layer chromatography results. Because of the fact that no statistically significant difference $(\mathrm{P}<$ 0.05) was observed between fructose and glucose contents in the sapwood, these compounds were the major soluble NSC of the sapwood. Like starch, the concentration of glucose and fructose decrease from the sapwood to the inner heartwood. In heartwood, trace amounts of soluble NSC were found (Figure 3B). Sucrose 


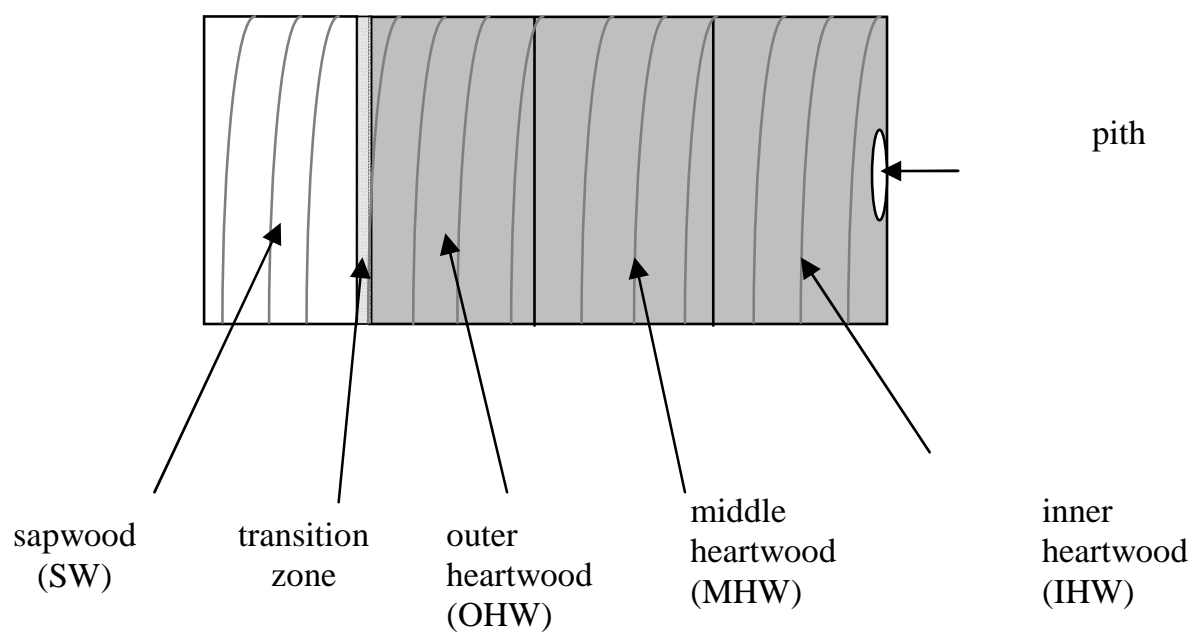

Figure 1: Graphic describing the wood samples used for analyses. A transversal wood slice was sawn from stem discs of the different trees.

Wood samples are indicated by white or grey rectangles for one radius in the picture and were collected from sapwood (SW), outer heartwood (OHW), middle heartwood (MHW) and inner heartwood (IHW). The transition zone was identified by the difference in colour between the sapwood and the heartwood.

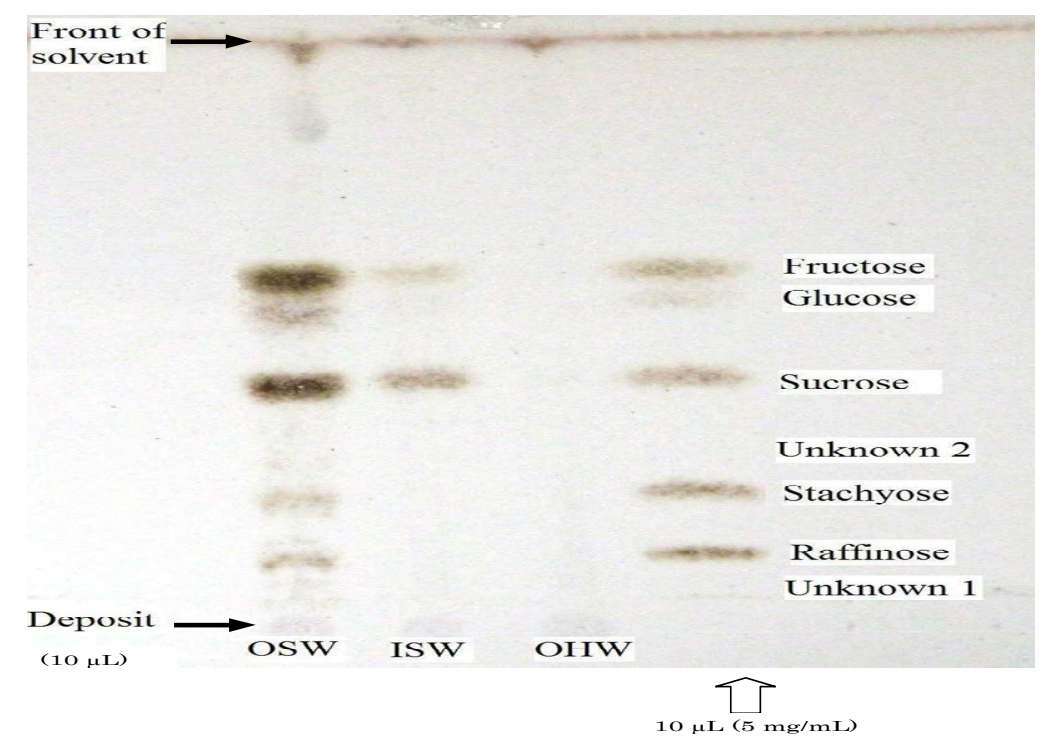

Figure 2: Thin layer chromatography of soluble non-structural carbohydrates extracted from the outer sapwood (OSW), the inner sapwood (ISW) and the outer heartwood (OHW) of teak (Tectona grandis L. f.) (tree 5). Glucose, fructose, sucrose, stachyose and raffinose are used as standards. Spots were visualised by spraying with the following chemical: diphenylamine / aniline / acetone / orthophosphoric acid (1/1/100/10, w/v/v/v). 


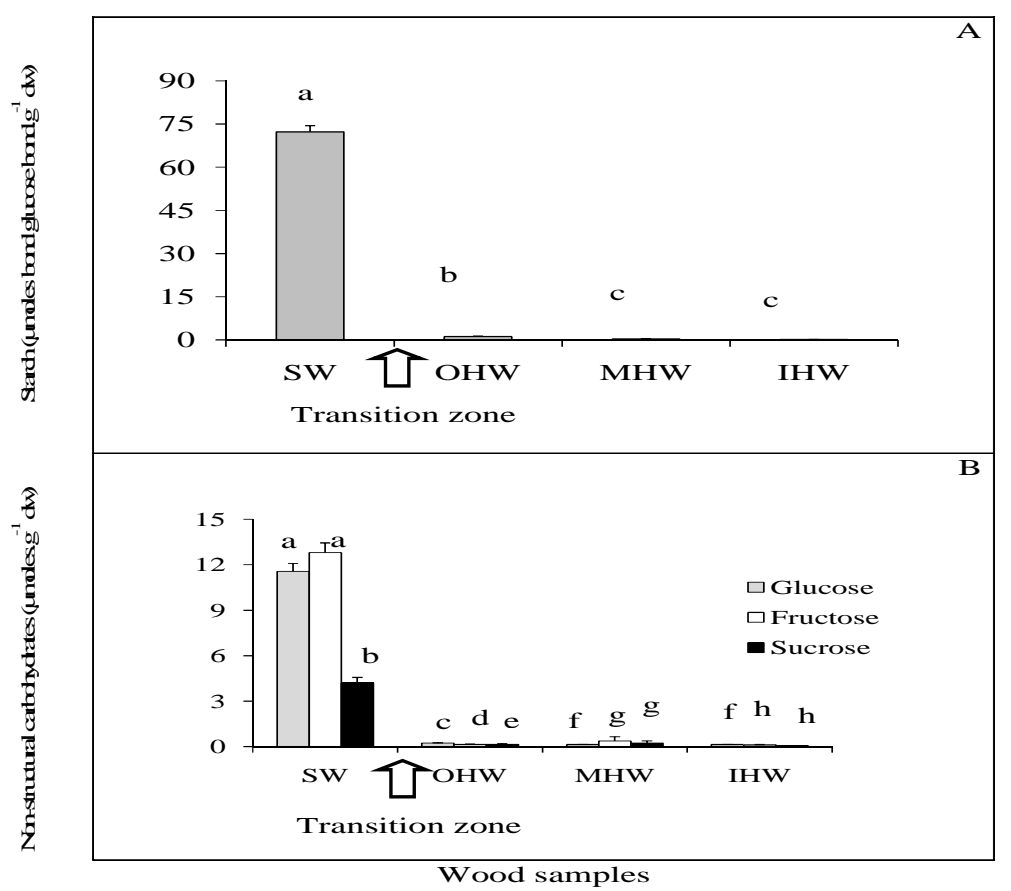

Figure 3: Non-structural carbohydrates (NSC) content in teak (Tectona grandis L. f.): starch (A) and soluble NSC (B) in the sapwood (SW) and the heartwood that is divided in outer heartwood (OHW), middle heartwood (MHW) and inner heartwood (IHW).

Values represent the mean for the 7 trees in the sapwood, the outer heartwood, the inner heartwood and 6 trees in the middle heartwood. Standard deviations are displayed as bars. a, b, c, d, e, f, g and h indicate statistically significant values using the Mann-Whitney test when $\mathrm{P}<0.05$. The arrow indicates the transition zone between the sapwood and the heartwood.

Table 1: Tree characteristics of Tectona grandis L. f. From Malaysia

\begin{tabular}{llccc}
\hline Tree number & Locality & Age (years) & Girth $(\mathbf{c m})$ & Height $(\mathbf{m})$ \\
\hline 1 & Luasong & 10 & 43.0 & 12.0 \\
2 & Luasong & 7 & 62.5 & 15.5 \\
3 & Luasong & 10 & 67.0 & 19.5 \\
4 & Luasong & 10 & 60.0 & 19.0 \\
5 & Taliwas & 5.5 & 59.0 & 24.3 \\
6 & Taliwas & 5.5 & 59.0 & 18.0 \\
7 & Luasong & 7 & 55.0 & 17.0 \\
\hline
\end{tabular}


Table 2: Mean values of total amounts of non-structural carbohydrates and proportions of glucose, fructose, sucrose and starch in teak (Tectona grandis L. f.). Standard deviations (SD) are in parentheses.

\begin{tabular}{|c|c|c|c|c|c|}
\hline $\begin{array}{l}\text { Non-structural } \\
\text { carbohydrates }\end{array}$ & $\begin{array}{c}\text { Starch } \\
(\%)\end{array}$ & $\begin{array}{c}\text { Glucose } \\
(\%)\end{array}$ & $\begin{array}{c}\text { Fructos } \\
\text { e (\%) }\end{array}$ & $\begin{array}{c}\text { Sucrose } \\
(\%)\end{array}$ & $\begin{array}{c}\text { Total non-structural } \\
\text { carbohydrates } \\
\left(\mu \text { moles.g }{ }^{-1} \text { DW }\right)\end{array}$ \\
\hline Sapwood & 71.8 & 11.5 & 12.7 & 4.2 & $98.5(2.8)$ \\
\hline Outer heartwood & 70.3 & 14.4 & 9.0 & 10.0 & $1.65(0.2)$ \\
\hline Middle heartwood & 39.0 & 13.4 & 36.2 & 22.3 & $1.05(0.4)$ \\
\hline Inner heartwood & 47.3 & 25.5 & 21.5 & 12.8 & $0.55(0.0)$ \\
\hline
\end{tabular}

concentrations were the lowest of all quantified NSC (Figure 3A) and decreased from the sapwood to inner heartwood.

The radial distribution of NSC was similar in all studied trees $(\mathrm{P}>0.05)$ as general patterns: starch $>$ glucose, fructose $>$ sucrose except for the tree 6 where fructose content was significantly higher than glucose content $(\mathrm{p}<0.004)$. Qualitatively, the radial patterns of NSC were found to be similar in all trees. But quantitatively, a tree-effect $(\mathrm{H}=$ $13.1 ; \mathrm{p} \leq 0.000$ ) was observed for the content of sucrose and starch.

\section{DISCUSSION}

Non-structural carbohydrates (NSC) are primary molecules used for metabolic processes in plants especially, in woody plants (Hansen et al., 1997). Our objective was to characterize and quantify main non-structural carbohydrates in the radial profile of teak wood before its use by industry. Main nonstructural carbohydrates were determined using thin layer chromatography with the tree 5. However, to confirm the presence of the same main sugars in teak, complementary TLC experiment were conducted using another tree which was randomly selected (data not shown).

In teak wood, eight NSC were found: glucose, fructose, sucrose, stachyose, raffinose, two unknown compounds and starch. Starch was found to be the major part of the NSC. This result is in good accordance with that observed in tropical species Pseudobombax septenatum and Astronium graveolens (Würth et al., 2005) and Thailand teak (Nobuchi et al., 2005) and in temperate species like Robinia pseudoacacia (Magel et al., 1994). As observed with starch, soluble NSC were highly accumulated in the sapwood and decreased abruptly from the sapwood to the outer heartwood. Similar results were found in Fagus sylvatica and Pinus sylvestris, two temperate species (Magel and Höll, 1993; Magel et al., 1997). The drastic decrease of the content of starch and soluble sugars from the sapwood to the heartwood suggests that NSC were used in the sapwood-heartwood boundary. This may show that the inner sapwood could be a strong sink of NSC which were degraded for energy and the carbon skeleton needed for metabolic activities such as cell respiration, photosynthesis and the 
formation of secondary metabolites such as phenolics (Magel et al., 1994; Datta and Kumar, 1987). Indeed, the sapwoodheartwood boundary was shown to be the site where highest catabolic activities of NSC occurred (Magel et al., 2001). In this zone, starch could be hydrolyzed into glucose under action of a hydrolyzing enzyme like amyloglycosidase (Magel et al., 1997; Magel et al., 2001). In addition, Datta and Kumar, (1987) showed that in teak wood, key enzymes of NSC catabolism like dehydrogenase succinate and glucose-6phosphate were involved in the activities of reduced NSC and were accumulated in the inner sapwood and in the transition zone. In teak, NSC were located in the youngest parts of the wood, precisely in axial and radial parenchyma cells (Nobuchi et al., 1996).

Soluble NSC were mainly monomeric NSC (fructose and glucose) while polymeric soluble NSC (sucrose, raffinose and stachyose) were weakly accumulated in teak sapwood. In the present study, the concentrations of sucrose found in teak were low and different from those observed in temperate species like Robinia pseudoacacia, Pinus sylvestris or Fagus sylvatica. In these species, sucrose was found to be the dominant soluble NSC (Magel et al., 1997). The low content of sucrose may show a reduction of activity of transport in the phloem as observed in teak wood from Thailand. The relative low phloem activity could be related to the harvest season (Nobuchi et al., 2005) which corresponds to the beginning of the dry season (dormancy period) and indicates a high enzymatic hydrolysis of sucrose into glucose and fructose (Magel et al., 1994). This is emphasized by the abundance of glucose and fructose in the soluble NSC fraction. Sucrose might be hydrolyzed by sucrose synthase
(Susy) and invertase which are key enzymes for sucrose metabolic activities (Déjardin et al., 1997; Novitskaya et al., 2006). Since sucrose and starch inter-conversion occurred in woody plants (Cunningham et al., 2003), we cannot exclude the possibility that sucrose might convert into starch and also that further reactions could occur during sample collection and conservation periods.

Surprisingly, stachyose and raffinose (the two sucrose galactosides) were detected in teak which is a tropical species. This result was unexpected because stachyose and raffinose played a particular role in the resistance to frost of temperate species like Betula platyphylla var. japonica (Kasuga et al., 2007). In teak, stachyose and raffinose may have different roles. They could involved in tree phenology such as flowering, fructifying, sprouting etc., as suggested by Höll (1997) and observed in Pistacia vera trees (Spann et al., 2008) and Pinus sylvestris (Kaipiainen and Sofronova, 2003).

In addition, the pattern of NSC in individual trees was the same as the general pattern indicating that the mobilisation of NSC can be considered as a stable process which is under genetic control and can be studied on a tree level. However, the mobilisation of sucrose and starch varied between trees and could be controlled by the intrinsic characteristics of the tree such as heritability and generally genetic factors. This variability could also be explained by a tree age-effect but this factor was not taking into account for the present study due to a limited number of the repetition for different age trees.

Our results showed that in teak, main NSC (starch, glucose, fructose and sucrose) were highly present in living parts of the wood and decreased during heartwood 
formation process. Stored forms of NSC were starch and sucrose which were hydrolyzed into monosaccharides in the transition zone for energy and carbon skeleton needed for metabolic processes. Variations of NSC from the sapwood to the heartwood revealed that the inner sapwood could be a strong sink in teak wood and the transition zone was the site of utilisation of NSC. The depletion of NSC through the radial direction suggests that they may be precursors for the synthesis of wood extractives like phenolic compounds during heartwood formation in teak as shown by Magel et al. (1994) for Robinia pseudoacacia. Further studies on the composition of phenolic compounds and their relationships to NSC may provide relevant knowledge about chemical differences between sapwood and heartwood in teak and heartwood formation process. In addition, the role of raffinose and stachyose in teak needs more investigation.

\section{Conclusion}

We studied radial distribution of nonstructural carbohydrates in the stem of plantation teak from Malaysia. Eight nonstructural carbohydrates (starch, glucose, fructose, sucrose, raffinose, stachyose and two unknown non-structural carbohydrates) were detected in teak wood. They were highly accumulated in the sapwood and depleted abruptly in the heartwood. Our results confirmed that non-structural carbohydrates play a key role during heartwood formation and might be responsible for the formation of heartwood phenolic compounds. However, in teak, even if the mobilisation of non-structural carbohydrates was found to be qualitatively stable, the content of sucrose and starch may quantitatively be related to intrinsic characteristics of the tree. More investigations are now required about the physiological role of the non-structural carbohydrates like raffinose and stachyose in a tropical tree and about the becoming of non-structural carbohydrates.

\section{ACKNOWLEDGEMENTS}

The authors are grateful to the International Tropical Timber Organisation (ITTO) for its financial support.

\section{REFERENCES}

Behaghel I. 1999. Etat des plantations de teck (Tectona grandis L. f.) dans le monde. Bois et Forêts Tropiques, 262(4): 5-18.

Bhat KM, Florence MEJ. 2003. Natural Decay Resistance of Juvenile Teak Wood Grown in High Input Plantations. Holzforsch, 57: 453-455.

Bhat KM, Thulasidas PK, Florence MEJ, Jayaraman K. 2005. Wood durability of home-garden teak against brown-rot and white-rot fungi. Trees, 19: 654-660.

Cunningham SM, Nadeau P, Castonguay Y, Laberge S, Volenec JJ. 2003. Crop physiology and metabolism: raffinose and stachyose accumulation, galactinol synthase expression, and winter injury of contrasting alfalfa germplasms. Crop Sci., 43: 562-570.

Datta SK, Kumar A. 1987. Histochemical studies of the transition from sapwood to heartwood in Tectona grandis. IAWA Bull., 8(4): 363-368.

Déjardin AC, Rochat S, Maugenest JP, Boutin. $1997 . \quad$ Purification, characterisation and physiological role of sucrose synthase in the pee seed coat (Pisum sativum L.). Planta, 201: 128-137.

Duroux L, Delmotte FM, Lancelin JM, Ravis GKE, and Jay-Allemand C. 1998. Insight into naphthoquinone metabolism: $\beta$ glucosidase-catalysed hydrolysis of 
hydrojuglone $\quad \beta$-D-glucopyranoside. Biochem. J., 333: 275-283.

Goh DKS, Monteuuis O. 2009. Status of the YSG Biotech program of building teak genetic resources in Sabah. Bois et Forêts Tropiques, 301(3): 33-49.

Hansen JR, Türk G, Vogg R, Heim EB. 1997. Conifer carbohydrates physiology: updating classical views. In Trees Contributions to Modern Tree Physiology, Rennenberg H, Eschrich W, Ziegler H, (eds). Backhuys Publishers Leiden: The Netherlands; 97-108.

Höll W. 1997. Storage and mobilization of carbohydrates and lipids. In Trees Contributions to Modern Tree Physiology, Rennenberg H, Eschrich W, Ziegler $\mathrm{H}$ (eds). Backhuys Publishers Leiden: The Netherlands; 197-211.

Kaipiainen LK, Sofronova GI. 2003. The Role of the Transport System in the Control of the Source-Sink Relations in Pinus sylvestris., 50(1): 125-132.

Kaosa-ard A. 1999. Teak (Tectona grandis Linn. F.), Domestication and breeding. Teaknet Publication, 5: 86.

Kasuga J, Arakawa K, Fujikawa S. 2007. High accumulation of soluble sugars in deep supercooling Japanese white birch xylem parenchyma cells. New Phytol., 174: 569-579.

Kokutse AD, Baillères H, Stokes A, Kokou K. 2004. Proportion and quality of heartwood in Togolese teak (Tectona grandis L.f.). For. Ecol. Manag., 189(1-3): 37-48.

Kokutse AD, Stockes A, Kokutse NK, Kokou K. 2010. Which factors most influence heartwood distribution and radial growth in plantation teak? Ann. For. Sci., 67: 407.

Magel E, Höll W. 1993. Storage carbohydrates and adenine nucleotides in trunks of Fagus sylvatica L. in relation to Discolored Wood. Holzforsch., 47: 19-24.

Magel E, Jay-Allemand C, Ziegler H. 1994. Formation of heartwood substances in the stemwood of Robinia pseudoacacia L. II. Distribution of nonstructural carbohydrates and wood extractives across the trunk. Trees, 8: 165-171.

Magel E, Hillinger C, Höll W, Ziegler H. 1997. Biochemistry and physiology of heartwood formation: Role of reserve substances. In Trees - Contributions to Modern Tree Physiology, Rennenberg H, Eschrich W, Ziegler H (eds). Backhuys Publishers Leiden: The Netherlands; 477506.

Magel E, Abdel-Latif A, Hampp R. 2001. Non-Structural Carbohydrates and catalytic activities of sucrose metabolizing enzymes in trunks of Two Juglans Species and their role in heartwood formation. Holzforsch., 55: 135-145.

Moya R, Berrocal A, Serrano JR, Tomazello Fo M. 2009. Variación radial de la anatomía, densidad y durabilidad de la madera de teca (Tectona grandis) procedente de dos calidades de sitio y dos regiones climáticas de Costa Rica. Investigación Agraria: Sistemas y Recursos Forestales, 18(2): 119-131.

Nobuchi T, Janmahasatien S, Sakai M. 1996. Seasonal changes of wood formation and some characteristics of heartwood formation in teak (Tectona grandis L.) plantation. Kasetsart J. Nat. Sci., 30(2): 254-263.

Nobuchi T, Okada N, Nishida M, Siripatanadilok S, Veenin T, Tobing TL, Sahri MH. 2005. Some characteristics of wood formation in Teak (Tectona grandis) with special reference to water conditions. In Quality Timber Products of 
Teak from Sustainable Forest Management, Bhat KM, Nair KKN, Bhat KV, Muralidharan EM, Sharma JK (eds). India; 495-499.

Novitskaya LL, Kushnir FV. 2006. The Role of Sucrose in Regulation of Trunk Tissue Development in Betula pendula Roth. $J$ Plant Growth Regul., 25: 18-29.

Pandey D, Brown C. 2000. Le teck dans le monde. Unasylva., 201(51): 3-13.

Silpi U, Lacointe A, Kasempsap P, Thanysawanyangkura S, Chantuma P, Gohet E, Musigamart N, Clément A, Améglio T, Thaler P. 2007. Carbohydrate reserves as a competing sink: evidence from tapping rubber trees. Tree Physiology, 27: 881-889.
Spann TM, Beede RH, Dejong TM. 2008. Seasonal carbohydrate storage and mobilization in bearing and non-bearing pistachio (Pistacia vera) trees. Tree Physiology, 28: 207-213.

Thulasidas PK, Bhat KM. 2007. Chemical extractive compounds determining the brown-rot decay resistance of teak wood. Holz Roh-Werkst., 65: 121-124.

Thulasidas PK, Bhat KM, Okuyama T. 2006. Heartwood colour variation in home garden teak (Tectona grandis) from wet and dry localities of Kerala, India. $J$. Tropical For. Sci., 18(1): 51-54.

Würth MK, Pelaèz-Riedl RS, Körner SJWC. 2005. Non-structural carbohydrate pools in a tropical forest. Oecologia, 143: 1124. 